\title{
Retraction Note to: Artificial neural networks for prediction compressive strength of geopolymers with seeded waste ashes
}

\author{
Ali Nazari ${ }^{1}$
}

Published online: 18 June 2020

(c) Springer-Verlag London Ltd., part of Springer Nature 2020

\section{Retraction note to: Neural Comput \& Applic (2013) 23:391-402 https://doi.org/10.1007/s00521-012-0931-4}

The Editor-in-Chief has retracted this article [1] because it significantly overlaps with a number of articles including those that were under consideration at the same time [2], and previously published articles [3-6]. Additionally, the article shows evidence of peer review manipulation. The author has not responded to any correspondence regarding this retraction.

\section{References}

1. Nazari A (2013) Artificial neural networks for prediction compressive strength of geopolymers with seeded waste ashes. Neural Comput Appl 23:391-402. https://doi.org/10.1007/s00521-0120931-4

2. Nazari A (2012) Artificial neural networks for prediction of percentage of water absorption of geopolymers produced by waste ashes. Bull Mater Sci 35:1019-1029. https://doi.org/10.1007/ s12034-012-0380-9

3. Nazari A, Riahi S (2013) Artificial neural networks to prediction total specific pore volume of geopolymers produced from waste ashes. Neural Comput Appl 22:719-729. https://doi.org/10.1007/ s00521-011-0760-x

4. Bohlooli H, Nazari A, Khalaj G, Kaykha MM, Riahi S (2012) Retracted: Experimental investigations and fuzzy logic modeling of compressive strength of geopolymers with seeded fly ash and rice husk bark ash. Compos Part B: Eng 43(3):1293-1301. https:// doi.org/10.1016/j.compositesb.2012.01.012

5. Nazari A, Riahi S, Khalaj G, Bohlooli H, Kaykha MM (2012) Retracted: Prediction of compressive strength of geopolymers with seeded fly ash and rice husk-bark ash by gene expression programming. Int J Damage Mech 21(8):1202-1226. https://doi. org/10.1177/1056789511431991

6. Nazari A, Khalaj G, Riahi S (2013) ANFIS-based prediction of the compressive strength of geopolymers with seeded fly ash and rice husk-bark ash. Neural Comput Appl 22:689-701. https://doi.org/ 10.1007/s00521-011-0751-y

Publisher's Note Springer Nature remains neutral with regard to jurisdictional claims in published maps and institutional affiliations.
The original article can be found online at https:// doi.org/10.1007/s00521-012-0931-4.

\section{Ali Nazari}

alinazari84@aut.ac.ir

1 Department of Materials Science and Engineering, Saveh Branch, Islamic Azad University, Saveh, Iran 